\title{
Mesorhizobium australicum sp. nov. and Mesorhizobium opportunistum sp. nov., isolated from Biserrula pelecinus L. in Australia
}

Correspondence

Kemanthi G. Nandasena kemanthi@murdoch.edu.au

\author{
Kemanthi G. Nandasena, ${ }^{1}$ Graham W. O'Hara, ${ }^{1}$ Ravi P. Tiwari, ${ }^{1}$ \\ Anne Willems ${ }^{2}$ and John G. Howieson ${ }^{1}$ \\ ${ }^{1}$ Centre for Rhizobium Studies, Murdoch University, Murdoch, Western Australia 6160, Australia \\ ${ }^{2}$ Laboratory of Microbiology, Faculty of Sciences, Ghent University, B-9000 Ghent, Belgium
}

Biserrula pelecinus L. is an important pasture species in sustainable farming systems in Australia because it is one of few deep-rooted, acid-tolerant forage legume species with the potential to reduce the development of dry-land salinity (Howieson et al., 2000; Loi et al., 2005). We have reported recently that root nodule isolates from $B$. pelecinus growing in the Mediterranean basin, the centre of origin for this species (Allen \& Allen, 1981), belong to

The GenBank/EMBL/DDBJ accession numbers for the 16S rRNA gene sequences of strains WSM2073 ${ }^{\top}$ and WSM2075 ${ }^{\top}$ are AY601516 and AY601515, respectively. Accession numbers for the dnaK gene sequences of strains WSM2073 ${ }^{\top}$ and WSM2075 ${ }^{\top}$ are DQ485744 and DQ485746, respectively, and those for the GSI/ gene sequences were DQ485752 and DQ485754, respectively. Accession numbers for the dnaK gene sequences of the type strains of Mesorhizobium amorphae, M. ciceri, M. chacoense, M. huakuii, M. plurifarium, M. tianshanense, M. septentrionale, M. temoeratum, M. thiogangeticum and M. albiziae are FM164381-FM164390, respectively.

Neighbour-joining phylogenetic trees based on dnaK and GS/l gene sequences showing the positions of the novel isolates WSM2073', WSM2074, WSM2075 ${ }^{\top}$ and WSM2076, Mesorhizobium ciceri bv. biserrulae isolated from the Mediterranean basin and other root-nodule bacteria in the Alphaproteobacteria, together with tables detailing differential phenotypic characteristics of the novel species described here and recognized species of

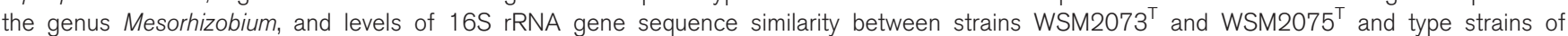
Mesorhizobium species are available as supplementary material with the online version of this paper. 
Mesorhizobium ciceri biovar biserrulae (Nandasena et al., 2007b). B. pelecinus was introduced to Australia in 1993, in regions where resident rhizobia failed to nodulate with it. However, we have recently shown the rapid evolution of nodulating bacterial strains for B. pelecinus in Australia via the in situ lateral transfer of a symbiosis island (a genomic island carrying genes required for nodulation and nitrogen fixation). The symbiosis island was transferred from the original inoculant strain Mesorhizobium ciceri bv. biserrulae WSM1271 to other soil bacteria (Nandasena et al., 2006). The recipient strains of the symbiosis island are hereafter referred to as novel isolates. This manuscript reports on the taxonomic status of four of these novel isolates $\left(\mathrm{WSM} 2073^{\mathrm{T}}=\mathrm{N} 17^{\mathrm{T}}, \mathrm{WSM} 2074=\mathrm{N} 18, \mathrm{WSM} 2075^{\mathrm{T}}=\mathrm{N} 45^{\mathrm{T}}\right.$ and WSM2076 $=$ N87).

The novel isolates WSM2073 ${ }^{\mathrm{T}}$, WSM2074 and WSM2076 formed finger-like, indeterminate nodules on B. pelecinus that fixed $\mathrm{N}_{2}$ poorly (Nandasena et al., 2007a). The symbiotic genes of these three isolates were located on a mobile symbiosis island, providing the ability to nodulate B. pelecinus, Astragalus membranaceus and Macroptilium atropurpureum. The three isolates had nearly identical sequences for a $1440 \mathrm{bp}$ internal region of the 16S rRNA gene (DNA amplification for the 16S rRNA gene and sequencing methods were as described by Nandasena et al., 2007a), with only $1 \mathrm{nt}$ mismatch among them. In the phylogenetic tree based on 16S rRNA gene sequences the novel isolates clustered together within the genus Mesorhizobium but were separate from all recognized species of this genus (Fig. 1). The three isolates were most closely related to Mesorhizobium ciceri bv. biserrulae, having $6 \mathrm{nt}$ mismatches (99.5\% 16S rRNA gene sequence similarity) and were most distantly related to Mesorhizobium thiogangeticum $\mathrm{SJT}^{\mathrm{T}}$ (97.1\%) (Table 1).

A fourth novel isolate, WSM $2075^{\mathrm{T}}$, formed small white nodules on $B$. pelecinus that were completely ineffective at

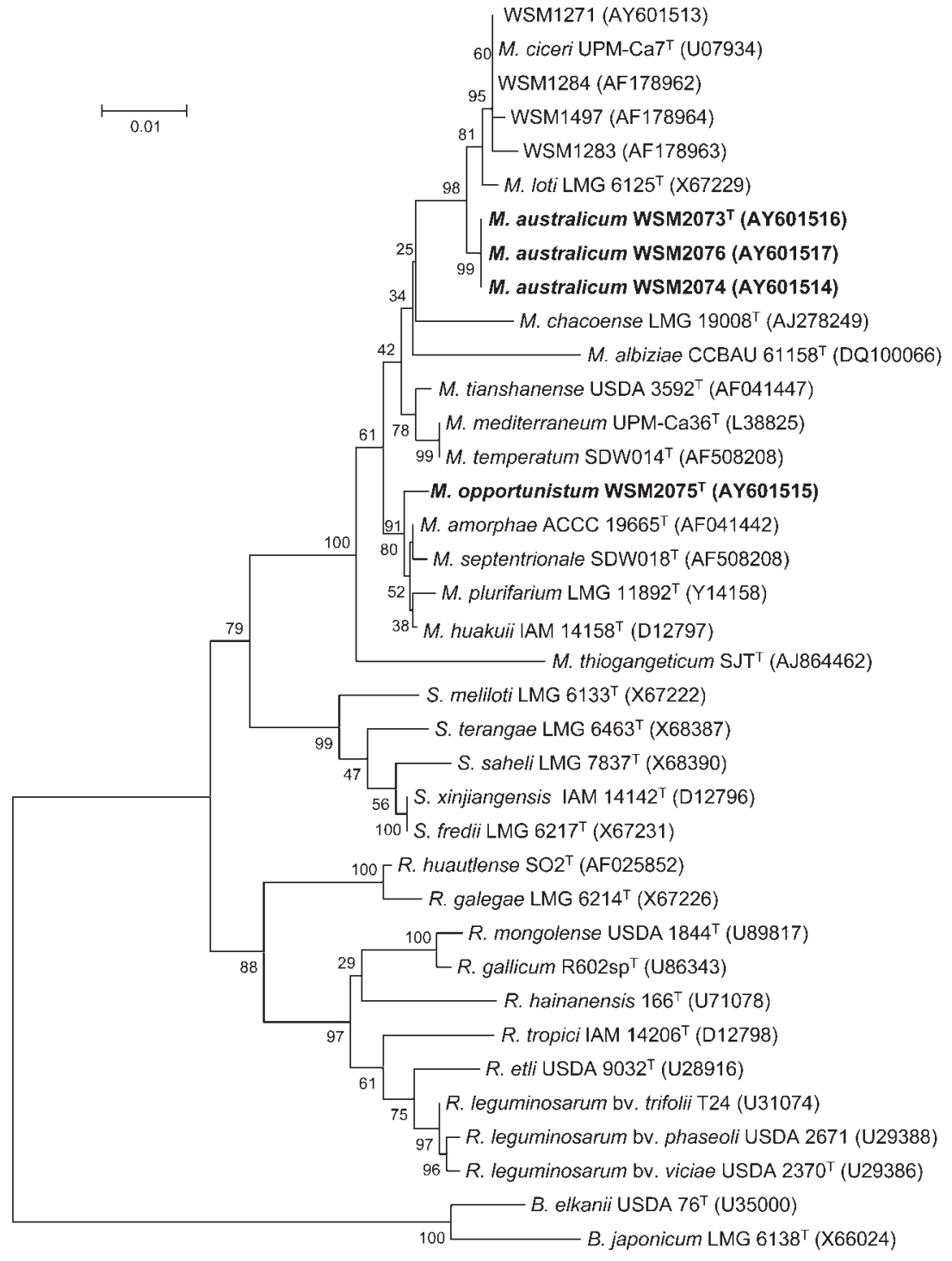

Fig. 1. Molecular phylogeny based on 16S rRNA gene sequences obtained from novel isolates WSM2073 ${ }^{\top}$, WSM2074, WSM2075 ${ }^{\top}$ and WSM2076, and Mesorhizobium ciceri bv. biserrulae WSM1271, WSM1283, WSM1284 and WSM1497, and other root-nodule bacteria in the Alphaproteobacteria. A sequence of $1440 \mathrm{bp}$ was analysed. All sites were informative and there were no gap-containing sites. Sequences were aligned by using the CLUSTAL W program in the Wisconsin package of the Genetics Computer Group (Madison, WI, USA) and a phylogenetic analysis was conducted by using MEGA version 3.1 (Kumar et al., 2004). Kimura two-parameter distances were derived from aligned sequences (Kimura, 1980) and bootstrap analysis (Felsenstein, 1985) was undertaken with 500 replicates to construct consensus unrooted trees via the neighbour-joining method (Saitou \& Nei, 1987). Abbreviations: $B$, Bradyrhizobium; $M$, Mesorhizobium; $R$, Rhizobium; S, Sinorhizobium. Bar, 0.01 changes per nucleotide position. 
Table 1. Levels of $16 \mathrm{~S}$ rRNA and dnaK gene sequence similarity, DNA G $+C$ content and levels of DNA-DNA relatedness for strains WSM2073 ${ }^{\top}$ and WSM2075 ${ }^{\top}$ and recognized species of the genus Mesorhizobium

NA, Data not available.

\begin{tabular}{|c|c|c|c|c|c|c|c|c|}
\hline \multirow[t]{2}{*}{ Strain } & \multirow{2}{*}{$\begin{array}{c}\text { DNA G + C } \\
\text { content } \\
(\mathrm{mol} \%)\end{array}$} & \multicolumn{3}{|c|}{${\text { WSM } 2073^{T}}^{T}$} & \multicolumn{3}{|c|}{ WSM $2075^{\mathrm{T}}$} & \multirow[t]{2}{*}{ Reference } \\
\hline & & $\begin{array}{l}\text { 16S rRNA } \\
\text { gene } \\
\text { sequence } \\
\text { similarity } \\
(\%)\end{array}$ & $\begin{array}{l}\text { dnaK gene } \\
\text { sequence } \\
\text { similarity } \\
(\%)\end{array}$ & $\begin{array}{l}\text { DNA-DNA } \\
\text { relatedness } \\
\quad(\%)\end{array}$ & $\begin{array}{l}\text { 16S rRNA } \\
\text { gene } \\
\text { sequence } \\
\text { similarity } \\
(\%)\end{array}$ & $\begin{array}{c}\text { dnaK gene } \\
\text { sequence } \\
\text { similarity } \\
\quad(\%)\end{array}$ & $\begin{array}{c}\text { DNA-DNA } \\
\text { relatedness } \\
(\%)\end{array}$ & \\
\hline WSM $2073^{\mathrm{T}}$ & 62.96 & - & - & 100 & 98.4 & 93.2 & 59 & This study \\
\hline WSM $2075^{\mathrm{T}}$ & 63.22 & 98.4 & 93.2 & 59 & - & - & 100 & This study \\
\hline $\begin{array}{l}\text { M. ciceri bv. Biserrulae } \\
\text { WSM1271 }\end{array}$ & 62.70 & 99.5 & 89.6 & NA & 98.3 & 91.0 & NA & $\begin{array}{l}\text { Nandasena et } \\
\text { al. (2007b) }\end{array}$ \\
\hline M. amorphae LMG $18977^{\mathrm{T}}$ & 63.37 & 98.4 & 91.1 & 37 & 99.6 & 91.9 & 40 & $\begin{array}{l}\text { Wang et al. } \\
\text { (1999) }\end{array}$ \\
\hline M. chacoense LMG $19008^{\mathrm{T}}$ & 62.04 & 98.0 & 88.4 & 16 & 98.3 & 89.0 & 17 & $\begin{array}{l}\text { Velázquez et } \\
\text { al. }(2001)\end{array}$ \\
\hline M. ciceri $\mathrm{LMG} 14989^{\mathrm{T}}$ & 64.34 & 99.3 & 89.9 & 35 & 98.1 & 91.4 & 36 & $\begin{array}{l}\text { Nour et al. } \\
\quad(1994 b, 1995)\end{array}$ \\
\hline M. huakuii LMG $14107^{\mathrm{T}}$ & 63.49 & 98.1 & 95.2 & 45 & 99.4 & 95.4 & 49 & $\begin{array}{l}\text { Chen et al. } \\
\text { (1991) }\end{array}$ \\
\hline M. huakuii MAFF303099 & NA & 98.7 & 91.4 & NA & 99.8 & 93.9 & NA & $\begin{array}{l}\text { Kaneko et al. } \\
\text { (2000) }\end{array}$ \\
\hline M. loti LMG $6125^{\mathrm{T}}$ & 62.70 & 99.3 & 91.4 & 45 & 98.1 & 93.5 & 50 & $\begin{array}{l}\text { Jarvis et al. } \\
(1982)\end{array}$ \\
\hline $\begin{array}{l}\text { M. mediterraneum LMG } \\
17148^{\mathrm{T}}\end{array}$ & 62.45 & 98.3 & 85.4 & 36 & 99.3 & 88.9 & 35 & $\begin{array}{l}\text { Nour et al. } \\
\quad(1994 b, 1995)\end{array}$ \\
\hline $\begin{array}{l}\text { M. plurifarium LMG } \\
11892^{\mathrm{T}}\end{array}$ & 62.83 & 98.0 & 86.8 & 42 & 99.3 & 88.2 & 47 & $\begin{array}{l}\text { de Lajudie et } \\
\text { al. (1998) }\end{array}$ \\
\hline $\begin{array}{l}\text { M. tianshanense LMG } \\
18976^{\mathrm{T}}\end{array}$ & 62.51 & 98.4 & 85.7 & 30 & 99.2 & 88.6 & 32 & $\begin{array}{l}\text { Jarvis et al. } \\
\text { (1997) }\end{array}$ \\
\hline $\begin{array}{l}\text { M. septentrionale LMG } \\
23930^{\mathrm{T}}\end{array}$ & 63.12 & 98.4 & 90.9 & 36 & 99.6 & 92.5 & 40 & $\begin{array}{l}\text { Gao et al. } \\
(2004)\end{array}$ \\
\hline $\begin{array}{l}\text { M. temperatum LMG } \\
23931^{\mathrm{T}}\end{array}$ & 62.22 & 98.4 & 91.6 & 29 & 99.4 & 93.6 & 28 & $\begin{array}{l}\text { Gao et al. } \\
(2004)\end{array}$ \\
\hline $\begin{array}{l}\text { M. thiogangeticum LMG } \\
22697^{\mathrm{T}}\end{array}$ & 60.72 & 97.1 & 86.9 & 11 & 98.1 & 87.2 & 11 & $\begin{array}{l}\text { Ghosh \& Roy } \\
\text { (2006) }\end{array}$ \\
\hline M. albiziae LMG $23507^{\mathrm{T}}$ & 59.00 & 98.1 & 80.0 & NA & 98.5 & 82.9 & NA & $\begin{array}{l}\text { Wang et al. } \\
\text { (2007) }\end{array}$ \\
\hline
\end{tabular}

fixing $\mathrm{N}_{2}$. The symbiotic genes of this organism were also located on a mobile symbiosis island, but provided a broader range of hosts for nodulation, including $B$. pelecinus, Astragalus adsurgens, A. membranaceus, Lotus peregrinus and Macroptilium atropurpureum. Strain WSM2075 ${ }^{\mathrm{T}}$ had a markedly different 16S rRNA gene sequence, with $>23 \mathrm{nt}$ mismatches with the other three novel isolates (Nandasena et al., 2007a). Strain WSM $2075^{\mathrm{T}}$ clustered with Mesorhizobium huakuii MAFF303099 (99.8\% 16S rRNA gene sequence similarity; Table 1, Fig. 1).

All four novel isolates shared 97-99\% 16S rRNA gene sequence similarity with the type strains of recognized species of the genus Mesorhizobium (Table 1). Brenner et al. (2005) stated that a ' $16 \mathrm{~S}$ rRNA gene sequence similarity of less than $97 \%$ between strains indicates that they represent different species, but at $97 \%$ or higher $16 \mathrm{~S}$ rRNA gene sequence similarity, DNA-DNA relatedness must be used to determine whether strains belong to different species'. Therefore, two housekeeping genes, dnaK (encoding a highly conserved chaperone protein with multiple cellular functions; Stepkowski et al., 2003) and GSII (encoding glutamine synthetase; Turner \& Young, 2000), were sequenced for the four novel isolates. Levels of DNADNA relatedness between strains WSM2073 ${ }^{\mathrm{T}}$ and WSM $2075^{\mathrm{T}}$ and the type strains of recognized Mesorhizobium species were determined. DNA amplification and sequencing methods for the above two genes were as described by Nandasena et al. (2007a). 
The novel isolates WSM2073 ${ }^{\mathrm{T}}$, WSM2074 and WSM2076 shared $>97.7 \%$ sequence similarity ( $<8 \mathrm{nt}$ mismatches) with each other for a $300 \mathrm{bp}$ intragenic fragment of the dnaK gene, but $<95.2 \%$ sequence similarity to the type strains of recognized Mesorhizobium species. Although these three strains were most closely related to Mesorhizobium ciceri bv. biserrulae based on their 16S rRNA gene, they showed highest $d n a K$ gene sequence similarity with the type strain of Mesorhizobium huakuii (Table 1) and clustered close to this species in the phylogenetic tree developed based on Kimura two-parameter distance values (Kimura, 1980) (Supplementary Fig. S1 in IJSEM Online). Interestingly, the $d n a K$ gene sequence of strain WSM $2075^{\mathrm{T}}$ was $<92.9 \%$ similar to those of the other three novel isolates, and this isolate was $<95.5 \%$ similar to the type strains of all Mesorhizobium species tested based on dnaK gene sequences. Strain WSM $2075^{\mathrm{T}}$ was also phylogenetically most closely related to Mesorhizobium huakuii, a result consistent with that obtained for 16S rRNA gene sequence phylogeny (Table 1 and Supplementary Fig. S1 available in IJSEM Online).

The novel isolates WSM2073 ${ }^{\mathrm{T}}$, WSM2074 and WSM2076 shared $>98.7 \%$ sequence similarity $(<9 \mathrm{nt}$ mismatches) with each other for a $600 \mathrm{bp}$ intragenic fragment of the GSII gene (Nandasena et al., 2007a) but showed $<90.7 \%$ GSII gene sequence similarity to strain WSM $2075^{\mathrm{T}}$. In the phylogenetic tree based on GSII gene sequences with Kimura two-parameter distance values (Kimura, 1980) strains WSM2073 ${ }^{\mathrm{T}}$, WSM2074 and WSM2076 clustered together but were distant and separate from other sequenced species of root-nodule bacteria (Supplementary Fig. S2, in IJSEM Online). These three strains were phylogenetically most closely related to Rhizobium etli whereas strain WSM2075 ${ }^{\mathrm{T}}$ clustered close to Mesorhizobium loti (Supplementary Fig. S2). Turner \& Young (2000) have reported the possible lateral transfer of the GSII gene amongst genera of root-nodule bacteria. Therefore, the above clustering pattern of the novel isolates is not surprising. Although GSII gene sequences may not be definitive for determining phylogenetic relationships of root-nodule bacteria, the above results indicate that the novel isolates belong to two separate species that have gained their GSII gene independently from different bacterial genera.

Cellular fatty acid profiles can provide a definitive tool in the identification of root-nodule bacteria and this analysis was undertaken for all four novel isolates as described by Tighe et al. (2000). Growth conditions, harvesting and extraction procedures were identical for all strains according to methods described by Sasser (1990). The fatty acids of these isolates included straight-chain saturated fatty acids, unsaturated fatty acids, 11-methyl branched unsaturated fatty acids and 3-hydroxy fatty acids (Table 2). These isolates also synthesized terminally isobranched fatty acids in higher amounts than Mesorhizobium ciceri bv. biserrulae, but less of the 10methyl branched fatty acids (Table 2). Although the fatty acid patterns of the novel isolates were diagnostic of root- nodule bacteria in general, these isolates could not be assigned to any of the recognized root-nodule bacterial species when their fatty acid patterns were compared with all the bacterial strains available in the Microbial Identification System fatty acid database. Furthermore, strain WSM $2075^{\mathrm{T}}$ had a significantly different fatty acid profile to the other three novel isolates (Table 2).

The carbon source utilization patterns for 14 compounds $(N$-acetylglucosamine, arabinose, arbutin, dulcitol, $\beta$ gentiobiose, lactose, maltose, melibiose, raffinose, sucrose, L-sorbose, D-tagatose, trehalose and turanose), antibiotic resistance [ampicillin $\left(50 \mu \mathrm{g} \mathrm{ml}^{-1}\right)$, chloramphenicol $\left(40 \mu \mathrm{g} \mathrm{ml}^{-1}\right), \quad$ gentamicin $\left(40 \mu \mathrm{g} \mathrm{ml}^{-1}\right)$, kanamycin $\left(50 \mu \mathrm{g} \mathrm{ml}^{-1}\right)$, nalidixic acid $\left(50 \mu \mathrm{g} \mathrm{ml}^{-1}\right)$, spectinomycin $\left(50 \mu \mathrm{g} \mathrm{ml}^{-1}\right)$, streptomycin $\left(100 \mu \mathrm{g} \mathrm{ml}^{-1}\right)$ and tetracycline $\left.\left(20 \mu \mathrm{g} \mathrm{ml}^{-1}\right)\right]$ and $\mathrm{pH}$ range for growth for the novel isolates were reported previously (Nandasena et al., 2007a). These phenotypic characteristics were compared with the data available for all recognized Mesorhizobium species (Supplementary Table S1, in IJSEM Online), and comparisons between the species that are phylogenetically most closely related to the novel isolates based on molecular methods are given in Table 3. Differences in carbon source utilization were observed for raffinose, dulcitol and melibiose for strains WSM $2073^{\mathrm{T}}$ and WSM $2075^{\mathrm{T}}$ and the type strains of Mesorhizobium ciceri, Mesorhizobium ciceri bv. biserrulae, Mesorhizobium huakuii and Mesorhizobium loti (Table 3). Differences were also observed for resistance to gentamicin amongst the above strains (Table 3).

The results obtained for 16S rRNA, dnaK and GSII gene sequencing and cellular fatty acid profiles strongly suggest that strains WSM2073 ${ }^{\mathrm{T}}$, WSM2074 and WSM2076 belong to one novel species of the genus Mesorhizobium, and that WSM $2075^{\mathrm{T}}$ may belong to another separate species within this genus. DNA-DNA hybridization experiments were performed [microplate method described by Ezaki et al. (1989) as modified by Goris et al. (1998)] with the type strains of 11 nodulating Mesorhizobium species to verify the above hypotheses (Table 1). Levels of DNA-DNA relatedness between WSM $2073^{\mathrm{T}}$ and WSM $2075^{\mathrm{T}}$ and the type strains of recognized Mesorhizobium species were $<45$ and $<50 \%$, respectively (Table 1 ). Strains WSM $2073^{\mathrm{T}}$ and WSM $2075^{\mathrm{T}}$ shared $59 \%$ DNA-DNA relatedness. These data clearly indicate that these two isolates belong to two separate novel species (Brenner et al., 2005) .

At the time of writing, the genus Mesorhizobium comprised 12 recognized species, 11 of which (Mesorhizobium albiziae, M. amorphae, M. chacoense, M. ciceri, M. huakuii, M. loti, $M$. mediterraneum, $M$. plurifarium, $M$. septentrionale, $M$. temperatum and $M$. tianshanense) have been shown to form nitrogen-fixing symbiotic associations with leguminous plants (Wang et al., 2007; Gao et al., 2004; Garrity, 2005; Ghosh \& Roy, 2006). The type strains of the above 11 species share $>97.8 \% 16 \mathrm{~S}$ rRNA gene sequence similarity (Supplementary Table S2, in IJSEM Online). Levels of dnaK gene sequence similarity are significantly lower and 
Table 2. Fatty acid profiles of the novel isolates and recognized species of the genus Mesorhizobium

Taxa: 1, M. ciceri; 2, M. huakuii; 3, M. mediterraneum; 4, M. loti; 5, M. tianshanense; 6, M. plurifarium; 7, M. ciceri bv. biserrulae; 8, strain WSM 2073 ; 9, strain WSM2074; 10, strain WSM2076; 11, strain WSM $2075^{\mathrm{T}}$. Values are percentages of the total fatty acids. Values in parentheses indicate standard deviation. Bold type indicates differences in fatty acids between the novel isolates and recognized species of Mesorhizobium. ND, Not detected.

\begin{tabular}{|c|c|c|c|c|c|c|c|c|c|c|c|}
\hline Fatty acid & $1^{\star}$ & $2^{\star}$ & $3^{*}$ & $4^{*}$ & $5^{*}$ & $6^{*}$ & 7 & 8 & 9 & 10 & 11 \\
\hline $\mathrm{C}_{12: 0} 3-\mathrm{OH}$ & $0.27(0.22)$ & $0.23(0.31)$ & $0.11(0.16)$ & $0.34(0.36)$ & $0.09(0.25)$ & $0.20(0.25)$ & 0.53 & 0.46 & 0.52 & 0.25 & 0.35 \\
\hline iso- $\mathrm{C}_{13: 0} 3-\mathrm{OH}$ & $0.24(0.23)$ & $1.00(0.26)$ & $0.35(0.28)$ & $1.23(0.35)$ & $0.27(0.38)$ & $0.84(0.43)$ & 0.45 & 0.78 & 0.70 & 0.54 & 0.9314 \\
\hline $\begin{array}{l}\text { Unknown (ECL } \\
14.780)\end{array}$ & $0.16(0.25)$ & ND & $0.04(0.15)$ & $\mathrm{ND}$ & ND & $0.01(0.06)$ & ND & $\mathrm{ND}$ & $\mathrm{ND}$ & $\mathrm{ND}$ & $\mathrm{ND}$ \\
\hline $\mathrm{C}_{15: 0}$ & $0.02(0.06)$ & $\mathrm{ND}$ & $0.04(0.13)$ & $\mathrm{ND}$ & ND & ND & 0.10 & 0.39 & 0.48 & 0.28 & $\mathrm{ND}$ \\
\hline anteiso- $\mathrm{C}_{15: 0}$ & ND & $\mathrm{ND}$ & $\mathrm{ND}$ & $0.12(0.51)$ & ND & ND & ND & $\mathrm{ND}$ & $\mathrm{ND}$ & ND & ND \\
\hline iso- $\mathrm{C}_{15: 0}$ & $0.18(0.23)$ & ND & $0.13(0.20)$ & $0.13(0.25)$ & $0.16(0.4)$ & ND & 0.21 & 0.62 & 0.73 & 0.77 & 0.20 \\
\hline $\mathrm{C}_{15: 1} \omega 8 c$ & ND & ND & ND & ND & ND & ND & 0.21 & ND & ND & ND & ND \\
\hline $\mathrm{C}_{16: 0}$ & $13.41(2.11)$ & $15.83(0.98)$ & $10.29(1.39)$ & $14.51(2.15)$ & $12.25(2.26)$ & $11.60(1.53)$ & 12.56 & 11.7 & 11.62 & 9.73 & 11.95 \\
\hline $\mathrm{C}_{17: 0}$ & $1.29(0.95)$ & $0.42(0.66)$ & $1.71(1.77)$ & $0.50(0.59)$ & $0.83(1.02)$ & $0.69(0.51)$ & 2.14 & 1.98 & 2.23 & 1.74 & 1.61 \\
\hline iso- $\mathrm{C}_{17: 0}$ & $4.16(0.69)$ & $5.88(1.13)$ & $4.19(1.14)$ & $8.17(1.93)$ & $3.34(0.68)$ & $6.26(0.77)$ & 4.18 & 3.67 & 3.22 & 4.86 & 4.98 \\
\hline $\mathrm{C}_{17: 0}$ cyclo & $0.84(0.38)$ & $0.70(0.52)$ & $0.85(0.82)$ & $0.69(0.51)$ & $0.16(0.3)$ & $0.12(0.23)$ & 0.58 & 1.32 & 0.86 & 0.59 & ND \\
\hline $\mathrm{C}_{17: 1} \omega 6 c$ & $\mathrm{ND}$ & ND & $\mathrm{ND}$ & ND & $0.11(0.32)$ & $0.09(0.26)$ & $\mathrm{ND}$ & $\mathrm{ND}$ & $\mathrm{ND}$ & ND & 0.41 \\
\hline $\mathrm{C}_{17: 1} \omega 8 c$ & $0.15(0.23)$ & $0.25(0.40)$ & $0.51(0.65)$ & $0.12(0.31)$ & $0.52(0.77)$ & $0.71(0.50)$ & 0.62 & 1.81 & 1.64 & 1.23 & 1.56 \\
\hline $\begin{array}{l}\text { Unknown (ECL } \\
17.875)\end{array}$ & $0.17(0.52)$ & ND & $0.50(0.99)$ & $\mathrm{ND}$ & ND & ND & ND & $\mathrm{ND}$ & $\mathrm{ND}$ & ND & $\mathrm{ND}$ \\
\hline $\mathrm{C}_{18: 0}$ & $3.25(1.25)$ & $4.10(0.48)$ & $4.21(1.59)$ & $4.50(1.22)$ & $4.99(0.72)$ & $2.99(1.22)$ & 2.65 & 1.85 & 2.36 & 2.47 & 2.04 \\
\hline $\begin{array}{l}\text { 11-methyl } \\
\mathrm{C}_{18: 1} \omega 7 c\end{array}$ & $11.92(3.61)$ & $4.82(2.77)$ & $5.57(4.33)$ & 11.14 & $9.99(1.38)$ & ND & 15.03 & 3.04 & 7.02 & 2.60 & 7.34 \\
\hline $\mathrm{C}_{18: 1} 2-\mathrm{OH}$ & $\mathrm{ND}$ & $0.11(0.32)$ & $\mathrm{ND}$ & $0.47(0.62)$ & ND & $\mathrm{ND}$ & ND & 0.30 & 0.54 & 0.68 & $\mathrm{ND}$ \\
\hline $\mathrm{C}_{18: 1} \omega 5 c$ & ND & $\mathrm{ND}$ & $0.06(0.21)$ & ND & ND & ND & ND & $\mathrm{ND}$ & ND & ND & ND \\
\hline $\mathrm{C}_{18: 1} \omega 7 c$ & ND & $\mathrm{ND}$ & $\mathrm{ND}$ & $\mathrm{ND}$ & $\mathrm{ND}$ & $\mathrm{ND}$ & ND & 53.75 & 58.43 & 62.34 & 61.74 \\
\hline $\mathrm{C}_{18: 1} \omega 9 c$ & $0.12(0.15)$ & $\mathrm{ND}$ & $\mathrm{ND}$ & $0.34(0.42)$ & ND & ND & 0.38 & $\mathrm{ND}$ & 0.28 & 0.28 & $\mathrm{ND}$ \\
\hline $\begin{array}{l}\text { Unknown (ECL } \\
18.794)\end{array}$ & 0.21 & $\mathrm{ND}$ & $0.32(0.49)$ & $0.08(0.18)$ & $0.11(0.31)$ & $0.25(0.35)$ & $\mathrm{ND}$ & $\mathrm{ND}$ & $\mathrm{ND}$ & ND & $\mathrm{ND}$ \\
\hline $\mathrm{C}_{19: 0}$ & ND & $\mathrm{ND}$ & $\mathrm{ND}$ & ND & ND & ND & 0.23 & 0.41 & 0.54 & 0.66 & $\mathrm{ND}$ \\
\hline iso- $\mathrm{C}_{19: 0}$ & ND & ND & $\mathrm{ND}$ & ND & ND & $\mathrm{ND}$ & ND & $\mathrm{ND}$ & $\mathrm{ND}$ & 0.22 & ND \\
\hline $\mathrm{C}_{19: 0}$ cyclo $\omega 8 \mathrm{c}$ & $37.27(8.48)$ & $22.96(6.05)$ & $33.35(11.05)$ & $21.93(8.17)$ & $12.37(4.31)$ & $11.33(5.67)$ & 35.29 & 14.66 & 8.99 & 7.29 & 4.10 \\
\hline 10-methyl $C_{19: 0}$ & $0.18(0.28)$ & $1.16(0.45)$ & $0.08(0.19)$ & $1.23(0.45)$ & $0.16(0.44)$ & $1.28(0.56)$ & 0.81 & 1.03 & 0.80 & 0.66 & 0.99 \\
\hline $\mathrm{C}_{20: 0}$ & $0.05(0.11)$ & $0.04(0.15)$ & $\mathrm{ND}$ & $0.07(0.19)$ & ND & $0.04(0.10)$ & 0.27 & 0.39 & 0.56 & 1.24 & 0.37 \\
\hline $\mathrm{C}_{20: 1} \omega 9 t$ & $0.14(0.22)$ & ND & $0.46(0.40)$ & $0.15(0.26)$ & ND & $0.10(0.16)$ & ND & $\mathrm{ND}$ & ND & ND & ND \\
\hline $\mathrm{C}_{20: 2} \omega 6,9 c$ & $0.95(0.68)$ & $0.04(0.15)$ & $0.77(0.44)$ & $0.05(0.15)$ & ND & ND & 0.87 & 0.40 & 0.45 & ND & ND \\
\hline $\mathrm{C}_{20: 1} \omega 7 c$ & ND & $\mathrm{ND}$ & $\mathrm{ND}$ & ND & ND & ND & ND & 0.51 & 0.52 & 0.66 & 0.38 \\
\hline
\end{tabular}

$\checkmark{ }^{\star}$ Data from Tighe et al. (2000). 
Table 3. Differential phenotypic characteristics between the novel species described herein and closely related species of the genus Mesorhizobium

Species: 1, M. ciceri (data from Nour et al., 1994a, b; Velázquez et al., 2001); 2, M. huakuii (Chen et al., 1991; Velázquez et al., 2001); 3, M. loti (Jarvis et al., 1982; Velázquez et al., 2001); 4, M. ciceri bv. biserrulae (Nandasena et al., 2001, 2007a, b); 5, M. australicum sp. nov.; 6, M. opportunistum sp. nov. d, Differences observed between different strains of the same species; ND, not determined.

\begin{tabular}{|c|c|c|c|c|c|c|}
\hline Characteristic & 1 & 2 & 3 & 4 & 5 & 6 \\
\hline $\begin{array}{l}\text { Colony diameter }(\mathrm{mm}) \\
\text { (incubation time) }\end{array}$ & $2-4$ (3-5 days) & $2-4$ (5-6 days) & 1 (7 days) & $2-4$ (4-5 days) & 2-4 (3-4 days) & 2-4 (3-4 days) \\
\hline Generation time $(\mathrm{h})$ & $<6$ & $4-6$ & ND & $4-6$ & $4-6$ & $4-6$ \\
\hline $\begin{array}{l}\text { Maximum growth } \\
\text { temperature }\left({ }^{\circ} \mathrm{C}\right)\end{array}$ & 40 & 37 & 39 & ND & ND & ND \\
\hline $\mathrm{pH}$ range for growth & $5-10$ & $5-9.5$ & $4-10$ & $5.5-8$ & $5.5-9$ & $5.5-9$ \\
\hline $\begin{array}{l}\text { DNA G }+C \text { content } \\
(\mathrm{mol} \%)\left(T_{\mathrm{m}}\right)\end{array}$ & $63-64$ & $59-64$ & $59-64$ & 62.7 & 62.9 & 63.2 \\
\hline Arbutin & ND & ND & ND & + & d & + \\
\hline DL-Arabinose & + & + & + & + & + & + \\
\hline Dulcitol & $\mathrm{ND}$ & - & $\mathrm{ND}$ & + & - & - \\
\hline Lactose & + & + & + & $\mathrm{d}$ & d & + \\
\hline Maltose & + & + & + & $\mathrm{d}$ & d & + \\
\hline Melibiose & + & - & + & + & + & + \\
\hline$N$-Acetylglucosamine & + & ND & ND & + & d & + \\
\hline Sorbose & ND & ND & ND & - & - & - \\
\hline Sucrose & + & + & + & $\mathrm{d}$ & d & + \\
\hline Trehalose & + & + & + & $\mathrm{d}$ & $\mathrm{d}$ & + \\
\hline$\beta$-Gentiobiose & ND & ND & ND & + & + & + \\
\hline Ampicillin & - & - & - & - & - & - \\
\hline Chloramphenicol & + & ND & $\mathrm{ND}$ & - & - & - \\
\hline
\end{tabular}

cover a wider range (80.0-96.2\%). However, the type strains of two pairs of these species shared even higher dnaK gene sequence similarity: Mesorhizobium mediterraneum and Mesorhizobium temperatum (98.2\%) and Mesorhizobium amorphae and Mesorhizobium septentrionale (98.1\%). Consistent with previous reports (Stepkowski et al., 2003; Ormeño-Orrillo et al., 2006), our results indicate that the $d n a K$ gene is a more discriminating marker for species distinction in the genus Mesorhizobium than is the $16 \mathrm{~S}$ rRNA gene.

The considerable differences observed for the phenotypic and genotypic characteristics between the two groups of novel isolates suggest that they represent two novel species of the genus Mesorhizobium. We propose the name Mesorhizobium australicum sp. nov. for strains WSM2073 ${ }^{\mathrm{T}}$, WSM2074 and WSM2076, and the name Mesorhizobium opportunistum sp. nov. for strain WSM2075 ${ }^{\mathrm{T}}$.
Description of Mesorhizobium australicum sp. nov.

Mesorhizobium australicum (au.stra.li'cum. N.L. neut. adj. australicum pertaining to Australia, from where these bacteria were isolated).

Cells are Gram-negative rods. Moderately fast-growing, forming colonies of $2-4 \mathrm{~mm}$ in diameter within 3-4 days on half-strength lupin agar ( $1 / 2 \mathrm{LA}$; Howieson et al., 1988) and have a mean generation time of $4-6 \mathrm{~h}$ when grown in $1 / 2$ LA broth at $28{ }^{\circ} \mathrm{C}$. Colonies on $1 / 2 \mathrm{LA}$ are white, opaque, slightly domed, moderately mucoid, with smooth margins. Able to tolerate a $\mathrm{pH}$ range between 5.5 and 9.0. Utilizes arabinose, $\beta$-gentiobiose and melibiose as sole source of carbon. With the exception of strain WSM2074, is also able to utilize maltose, sucrose and trehalose but not dulcitol or L-sorbose. Sensitive to ampicillin (50 $\left.\mu \mathrm{g} \mathrm{ml}^{-1}\right)$, chloramphenicol $\left(40 \mu \mathrm{g} \mathrm{ml}^{-1}\right)$, spectinomycin $\left(50 \mu \mathrm{g} \mathrm{ml}^{-1}\right)$, streptomycin $\left(100 \mu \mathrm{g} \mathrm{ml}^{-1}\right)$ and tetra- 
cycline $\left(20 \mu \mathrm{g} \mathrm{ml}^{-1}\right)$, but resistant to gentamicin $\left(40 \mu \mathrm{g} \mathrm{ml}^{-1}\right)$, kanamycin $\left(50 \mu \mathrm{g} \mathrm{ml}^{-1}\right)$ and nalidixic acid $\left(50 \mu \mathrm{g} \mathrm{ml}^{-1}\right)$. Synthesizes the following fatty acids: $\mathrm{C}_{12: 0}$ 3- $\mathrm{OH}$, iso- $\mathrm{C}_{13: 0} 3-\mathrm{OH}, \mathrm{C}_{15: 0}$, iso- $\mathrm{C}_{15: 0}, \mathrm{C}_{16: 0}, \mathrm{C}_{17: 0}$, iso$\mathrm{C}_{17: 0}, \mathrm{C}_{17: 0}$ cyclo, $\mathrm{C}_{17: 1} \omega 8 c, \mathrm{C}_{18: 0}, 11$-methyl $\mathrm{C}_{18: 1} \omega 7 \mathrm{c}$, $\mathrm{C}_{18: 1} 2-\mathrm{OH}, \mathrm{C}_{18: 1} \omega 7 c, \mathrm{C}_{19: 0}, \mathrm{C}_{19: 0}$ cyclo $\omega 8 c, 10$-methyl $\mathrm{C}_{19: 0}, \mathrm{C}_{20: 0}$ and $\mathrm{C}_{20: 1} \omega 7 \mathrm{c}$. Some strains contain a nonsymbiotic plasmid $(\sim 500 \mathrm{~kb})$. The DNA G $+\mathrm{C}$ content of the type strain is $62.96 \mathrm{~mol} \%$ (HPLC).

The type strain, WSM $2073^{\mathrm{T}}\left(=\mathrm{LMG} 24608^{\mathrm{T}}=\mathrm{HAMBI}\right.$ $3006^{\mathrm{T}}$ ), was isolated from nodules on Biserrula pelecinus $\mathrm{L}$.

\section{Description of Mesorhizobium opportunistum sp. nov.}

Mesorhizobium opportunistum (op.por.tu.nis'tum. L. neut. adj. opportunistum after the opportunistic behaviour of the organism in obtaining symbiotic genes from other rootnodule bacteria and its ability to nodulate a broad range of legume hosts).

Cells are Gram-negative rods. Moderately fast-growing, forming colonies of $2-4 \mathrm{~mm}$ in diameter within 3-4 days on $1 / 2 \mathrm{LA}$ and have a mean generation time of $4-6 \mathrm{~h}$ when grown in $1 / 2 \mathrm{LA}$ broth at $28{ }^{\circ} \mathrm{C}$. Colonies on $1 / 2 \mathrm{LA}$ are white, opaque, slightly domed, moderately mucoid, with smooth margins. Able to tolerate a $\mathrm{pH}$ range between 5.5 and 9.0. Utilizes $\mathrm{N}$-acetylglucosamine, arabinose, arbutin, $\beta$-gentiobiose, lactose, maltose, melibiose, sucrose, D-tagatose, trehalose and turanose as sole source of carbon, but not dulcitol, raffinose or L-sorbose. Sensitive to ampicillin $\left(50 \mu \mathrm{g} \mathrm{ml}^{-1}\right)$, chloramphenicol $\left(40 \mu \mathrm{g} \mathrm{ml}^{-1}\right)$, spectinomycin $\left(50 \mu \mathrm{g} \mathrm{ml}^{-1}\right)$, streptomycin $\left(100 \mu \mathrm{g} \mathrm{ml}^{-1}\right)$ and tetracycline $\left(20 \mu \mathrm{g} \mathrm{ml}^{-1}\right)$, but resistant to gentamicin $\left(40 \mu \mathrm{g} \mathrm{ml}^{-1}\right)$, kanamycin $\left(50 \mu \mathrm{g} \mathrm{ml}^{-1}\right)$ and nalidixic acid $\left(50 \mu \mathrm{g} \mathrm{ml}^{-1}\right)$. Synthesizes the following fatty acids: $\mathrm{C}_{12: 0}$ 3- $\mathrm{OH}$, iso- $\mathrm{C}_{13: 0} 3-\mathrm{OH}$, iso- $\mathrm{C}_{15: 0}, \mathrm{C}_{16: 0}, \mathrm{C}_{17: 0}$, iso- $\mathrm{C}_{17: 0}$, $\mathrm{C}_{17: 1} \omega 8 c, \mathrm{C}_{18: 0}, 11$-methyl $\mathrm{C}_{18: 1} \omega 7 c, \mathrm{C}_{18: 1} \omega 7 c, \mathrm{C}_{19: 0}$ cyclo $\omega 8 c, 10$-methyl $\mathrm{C}_{19: 0}, \mathrm{C}_{20: 0}$ and $\mathrm{C}_{20: 1} \omega 7 c$. Does not contain any plasmids. The DNA $\mathrm{G}+\mathrm{C}$ content of the type strain is $63.22 \mathrm{~mol} \%$ (HPLC).

The type strain, WSM $2075^{\mathrm{T}}\left(=\mathrm{LMG} 24607^{\mathrm{T}}=\mathrm{HAMBI}\right.$ $3007^{\mathrm{T}}$ ), was isolated from nodules on Biserrula pelecinus L.

\section{Acknowledgements}

This work was supported by a post-doctoral research fellowship provided to the senior author by the Grains Research and Development Corporation (GRDC) within the National Rhizobium Program, and the Australian Research Council through project DP0880896. We thank Renata Coopman for excellent technical assistance. We also thank the DSMZ, Germany, for fatty-acid analysis.

\section{References}

Allen, O. N. \& Allen, E. K. (1981). The Leguminosae a Source Book of Characteristics, Uses and Nodulation. Madison, WI: The University of Wisconsin Press.
Brenner, D. J., Staley, J. T. \& Krieg, N. R. (2005). Classification of procaryotic organisms and the concept of bacterial speciation. In Bergey's Manual of Systematic Bacteriology, pp. 27-32. Edited by D. J. Brenner, N. R. Krieg, J. T. Staley \& G. M. Garrity. New York: Springer.

Chen, W. X., Li, G. S., Qi, Y. L., Wang, E. T., Yuan, H. L. \& Li, J. L. (1991). Rhizobium huakuii sp. nov. isolated from the root nodules of Astragalus sinicus. Int J Syst Bacteriol 41, 275-280.

de Lajudie, P., Willems, A., Nick, G., Moreira, F., Molouba, F., Hoste, B., Torck, U., Neyra, M., Collins, M. D. \& other authors (1998). Characterization of tropical tree rhizobia and description of Mesorhizobium plurifarium sp. nov. Int J Syst Bacteriol 48, 369-382.

Ezaki, T., Hashimoto, Y. \& Yabuuchi, E. (1989). Fluorometric deoxyribonucleic acid-deoxyribonucleic acid hybridization in microdilution wells as an alternative to membrane filter hybridization in which radioisotopes are used to determine genetic relatedness among bacterial strains. Int J Syst Bacteriol 39, 224-229.

Felsenstein, J. (1985). Confidence limits on phylogenies: an approach using the bootstrap. Evolution 39, 783-791.

Gao, J. L., Turner, S. L., Kan, F. L., Wang, E. T., Tan, Z. Y., Qiu, Y. H., Gu, J., Terefework, Z., Young, J. P. \& other authors (2004). Mesorhizobium septentrionale sp. nov. and Mesorhizobium temperatum sp. nov., isolated from Astragalus adsurgens growing in the northern regions of China. Int J Syst Evol Microbiol 54, 2003-2012.

Garrity, G. M. (2005). Bergey's Manual of Systematic Bacteriology. New York: Springer Science.

Ghosh, W. \& Roy, P. (2006). Mesorhizobium thiogangeticum sp. nov., a novel sulfur-oxidizing chemolithoautotroph from rhizosphere soil of an Indian tropical leguminous plant. Int J Syst Evol Microbiol 56, 91-97.

Goris, J., Suzuki, K., De Vos, P., Nakase, T. \& Kersters, K. (1998). Evaluation of a microplate DNA-DNA hybridization method compared with the initial renaturation method. Can J Microbiol 44, 1148-1153.

Howieson, J. G., Ewing, M. A. \& D’Antuono, M. F. (1988). Selection for acid tolerance in Rhizobium meliloti. Plant Soil 105, 179-188.

Howieson, J. G., O'Hara, G. W. \& Carr, S. J. (2000). Changing roles for legumes in Mediterranean agriculture: developments from an Australian perspective. Field Crops Res 65, 107-122.

Jarvis, B. D. W., Pankhurst, C. E. \& Patel, J. J. (1982). Rhizobium loti, a new species of legume root nodule bacteria. Int J Syst Bacteriol 32, 378-380.

Jarvis, B. D. W., van Berkum, P., Chen, W. X., Nour, S. M., Fernandez, M. P., Cleyet-Marel, J. C. \& Gillis, M. (1997). Transfer of Rhizobium loti, Rhizobium huakuii, Rhizobium ciceri, Rhizobium mediterraneum and Rhizobium tianshanense to Mesorhizobium gen. nov. Int J Syst Bacteriol 47, 895-898.

Kaneko, T., Nakamura, Y., Sato, S., Asamizu, E., Kato, T., Sasamoto, S., Watanabe, A., Idesawa, K., Kawashima, K. \& other authors (2000). Complete genome structure of the nitrogen-fixing symbiotic bacterium Mesorhizobium loti. DNA Res 31, 331-338.

Kimura, M. (1980). A simple model for estimating evolutionary rates of base substitutions through comparative studies of nucleotide sequences. J Mol Evol 16, 111-120.

Kumar, S., Tamura, K. \& Nei, M. (2004). MEGA3: integrated software for molecular evolutionary genetics analysis and sequence alignment. Brief Bioinform 5, 150-163.

Loi, A., Howieson, J. G., Nutt, B. J. \& Carr, S. J. (2005). A second generation of annual pasture legumes and their potential for inclusion in Mediterranean-type farming systems. Aust J Exp Agric 45, 289-299.

Nandasena, K. G., O'Hara, G. W., Tiwari, R. P., Yates, R. J. \& Howieson, J. G. (2001). Phylogenetic relationships of three bacterial 
strains isolated from the pasture legume Biserrula pelecinus L. Int J Syst Evol Microbiol 51, 1983-1986.

Nandasena, K. G., O'Hara, G. W., Tiwari, R. P. \& Howieson, J. (2006). Symbiotically diverse root-nodule bacteria able to nodulate Biserrula pelecinus L. emerge six years after introduction of this legume to Australia. Appl Environ Microbiol 72, 7365-7367.

Nandasena, K. G., O'Hara, G. W., Tiwari, R. P. \& Howieson, J. G. (2007a). In situ lateral transfer of symbiosis islands results in rapid evolution of diverse competitive strains of mesorhizobia suboptimal in symbiotic nitrogen fixation on the pasture legume Biserrula pelecinus L. Environ Microbiol 9, 2496-2511.

Nandasena, K. G., O'Hara, G. W., Tiwari, R. P., Willems, A. \& Howieson, J. G. (2007b). Mesorhizobium ciceri biovar. biserrulae, a new biovar of root nodule bacteria nodulating the pasture legume Biserrula pelecinus L. Int J Syst Evol Microbiol 57, 1041-1045.

Nour, S. M., Cleyetmarel, J. C., Beck, D., Effosse, A. \& Fernandez, M. P. (1994a). Genotypic and phenotypic diversity of Rhizobium isolated from chickpea (Cicer arietinum L.). Can J Microbiol 40, 345354.

Nour, S. M., Fernandez, M. P., Normand, P. \& Cleyetmarel, J. C. (1994b). Rhizobium ciceri sp nov, consisting of strains that nodulate chickpeas (Cicer arietinum L.). Int J Syst Bacteriol 44, 511-522.

Nour, S. M., Cleyet-Marel, J.-C., Normand, P. \& Fernandez, M. P. (1995). Genomic heterogeneity of strains nodulating chickpeas (Cicer arietinum L.) and description of Rhizobium mediterraneum sp. nov. Int J Syst Bacteriol 45, 640-648.

Ormeño-Orrillo, E., Vinuesa, P., Zúñiga-Dávila, D. \& MartínezRomero, E. (2006). Molecular diversity of native bradyrhizobia isolated from Lima bean (Phaseolus lunatus L.) in Peru. Syst Appl Microbiol 29, 253-262.
Saitou, N. \& Nei, M. (1987). The neighbor-joining method: a new method for reconstructing phylogenetic trees. Mol Biol Evol 4, 406425.

Sasser, M. (1990). Identification of bacteria by gas chromatography of cellular fatty acids, MIDI Technical Note 101. Newark, DE: MIDI Inc.

Stepkowski, T., Czaplinska, M., Miedzinska, K. \& Moulin, L. (2003). The variable part of the $d n a K$ gene as an alternative marker for phylogenetic studies of rhizobia and related alpha Proteobacteria. Syst Appl Microbiol 26, 483-494.

Tighe, S. W., de Lajudie, P., Dipietro, K., Lindström, K., Nick, G. \& Jarvis, B. D. W. (2000). Analysis of cellular fatty acids and phenotypic relationships of Agrobacterium, Bradyrhizobium, Mesorhizobium, Rhizobium and Sinorhizobium species using the Sherlock Microbial Identification System. Int J Syst Evol Microbiol 50, 787-801.

Turner, S. L. \& Young, J. P. (2000). The glutamine synthetases of rhizobia: phylogenetics and evolutionary implications. Mol Biol Evol 17, 309-319.

Velázquez, E., Igual, J. M., Willems, A., Fernández, M. P., Muñoz, E., Mateos, P. F., Abril, A., Toro, N., Normand, P. \& other authors (2001). Mesorhizobium chacoense sp. nov., a novel species that nodulates Prosopis alba in the Chaco Arido region (Argentina). Int J Syst Evol Microbiol 51, 1011-1021.

Wang, E. T., van Berkum, P., Sui, X. H., Beyene, D., Chen, W. X. \& Martinez-Romero, E. (1999). Diversity of rhizobia associated with Amorpha fruticosa isolated from Chinese soils and description of Mesorhizobium amorphae sp. nov. Int J Syst Bacteriol 49, 51-65.

Wang, F. O., Wang, E. T., Liu, J., Chen, Q., Sui, X. H., Chen, W. F. \& Chen, W. X. (2007). Mesorhizobium albiziae sp. nov., a novel bacterium that nodulates Albizia kalkora in a subtropical region of China. Int J Syst Evol Microbiol 57, 1192-1199. 